\title{
Mass screening in leprosy endemic areas of Turkey: preliminary report
}

\author{
T SAYLAN* \& A H AYTEKIN† \\ *Istanbul University Medical School, Department of Dermatology, \\ Istanbul, Turkey; †Uludag University Medical School, Department \\ of Community Health, Tip Fakultesi Ogretim Uyesi, Bursa, Turkey
}

\author{
Accepted for publication 12 January 1986
}

\begin{abstract}
Summary A multipurpose programme was devised to enable a research team of university personnel to cooperate with local health units with the following objects: 1, to find registered leprosy patients in selected areas and provide them with curative and rehabilitative services; 2 , to locate people known to have been in close contact with registered patients and keep them under surveillance; 3 , to screen the whole population in selected areas in order to find new cases; 4 , to undertake periodic examination of suspected cases; and 5, to provide on-the-spot training for health personnel in the control of leprosy. Because of a known high prevalence, the province of Van, situated in the eastern part of Turkey, on the Iranian border, was chosen, and in the first year of this project, two regions of this province were covered, with the examination of over 15,000 people. This report describes the methodology and preliminary findings and discusses some of the difficulties in the interpretation of results with regard to the total population coverage achieved by such a screening programme in 1984, and the previously recorded, official census figures. It is planned to continue and expand this research and to analyse results in a future publication.
\end{abstract}

\section{Introduction}

Data related to the epidemiology of leprosy is limited in Turkey, as in other parts of the world, when compared with other communicable diseases. The bacteriological characteristics of Mycobacterium leprae, the persistence of the disease in underdeveloped and developing countries, and the behaviour of the patients limit the success of leprosy control methods. The number of newly diagnosed leprosy cases is increasing considerably in countries where the disease is endemic or endemosporadic..$^{1,2}$

In Turkey, the fight against leprosy began in the early 1960s and within a few years the registered cases reached 3454 , and the general prevalence rate was calculated as $0 \cdot 11$ per thousand in 1964 . The method used for screening could not 
be considered as mass screening, because only two millions out of the 10.5 millions population were examined in the leprosy endemic areas, whereas for an effective leprosy control programme, it is necessary to examine everybody in the endemic area by house-to-house visits. As a matter of fact, Dr Dominguez, a WHO consultant in leprosy, prepared a report in 1966 in which he recognized the attempts at leprosy control in Turkey but criticized the method of screening used. ${ }^{3}$ Gradually, haphazard screening has been replaced by dispensary control. According to the official records, the number of the registered patients were 4140 with a prevalance of 0.09 per thousand in $1981 .{ }^{4}$ Figures are almost the same between 1964 and 1981.

Health units (health centres without beds) are the basis of the governmental public health services in Turkey. According to the characteristics of the area, health units were established per 5,000-10,000 population in order to provide polyvalent health services. Each health unit has one doctor, with nurses, midwives and health technicians as necessary. The duties of the health units include finding new cases and notifying them to the Directorate of Health, treatment of registered cases, and referral of those needing further treatment and rehabilitation ${ }^{5}$. The health units also inform the patients of possible local aid provided by the voluntary people or agencies. The staff of the leprosy dispensaries in the city centres supervise the services given by the health units.

Although the functional structure of the health units was organized to realize this kind of health service, some studies on diagnosis and the registration of new cases and the reliability of the leprosy prevalence (which was static during the last 20 years) gave the impression that the health units were not able to provide satisfactory services for leprosy control. ${ }^{6}$ Because, firstly, the problem of leprosy is underrated compared to the other health problems (e.g. $\mathrm{MCH}$, tuberculosis and environmental health) in Turkey. Secondly, the training of health personnel is not suitable to the needs of the country. In our opinion it is however possible to achieve success in leprosy control with the present health service system in Turkey without adding additional expensive programmes, provided that shortcomings in the training of health personnel as well as the administration of health services for leprosy control are corrected. ${ }^{7}$

\section{Objectives}

Investigators prepared a multipurpose research programme considering the functional structure of the health units and the situation of leprosy in Turkey. According to this programme, a research team was organized from the university personnel to cooperate with the local health personnel of the chosen areas to perform mass screening. The following objectives are the aim of the screening programmes: 
1 To find registered patients in selected areas, and if necessary to provide them with all the available curative and rehabilitative services.

2 To locate people known to have been in close contact with registered patients and keep them under surveillance for a period of 5 years.

3 To screen the whole population in selected areas in order to detect unknown cases and to find out whether they have ever been in contact with any leprous patients, and to arrange a suitable treatment programme for such cases.

4 To undertake periodical examination and observation of the suspected cases who are not known contacts.

5 Last but not least, to provide on-the-job training for health units' personnel about the control of leprosy, so that they do not consider themselves only as drug distributors but as qualified people interested in the problems of leprous patients and keeping the close family contacts under surveillance.

\section{Materials and methods}

According to the data in hand the highest prevalence of leprosy in Turkey is in the province of Van which is 1.0 per thousand. A pilot study carried out in 1983 gave an impression that the prevalence of the disease could be even higher. In order not to miss any leprosy cases or suspected ones, it was decided to undertake mass screening in the province of Van.

This province is situated in the east of Turkey right on the Iranian border and covers $19,062 \mathrm{~km}^{2}$. Total population of the province is almost 500,000 of which $312,000(62.5 \%)$ live in rural areas and $93.0 \%$ of rural settlers are spread around 560 villages with less than 2000 people each. Considering such factors as the vastness of the area, scattered settlement of the population, inefficient manpower, potential of the working group and the necessary quality of the research work, it has been decided to spread the work over a number of years instead of applying a programme that would cover the whole area of the province. In this preliminary report the results of the first study carried out in 1984 are given.

In the first year two regions of the Van province, namely Bahçesaray and Çaldıran, were chosen as study areas. There were 12,165 persons spread over 66 villages in Bahçesaray and 15,323 persons spread over 47 villages in Çaldıran. The first area is situated in the mountainous south-west part of Van and the second one is located on a high plateau in the north-east part of the province.

The study teams had prepared a working plan based on data obtained from the Directorate of Health of the Province and marked all the known cases on detailed maps of the regions. Before going to Van, study teams were organized. Each team consisted of 4 persons, mainly medical students who had volunteered to work on this investigation and had had one week's training on the clinical diagnosis of leprosy at the Leprosy Hospital.

Generally these groups reached the study areas by car and sometimes on foot 
where roads were unsuitable for cars. Mass screening and therapy are accepted as principal methods for the control of leprosy. ${ }^{8}$ Therefore, all the available people in each settlement were submitted to medical examination. In order to secure success in screening and to draw the people's interest to this end, one member of each team was assigned to deal with the other diseases and complaints of the people, and if possible to treat them. To enable effective services, the teams carried with them sufficient amounts of essential drugs, and distributed them free of charge to the patients in both areas. The people of two settlements (5610 persons) which have health units were left out of screening operations because screening would be carried out by the health unit personnel.

Considering field working conditions, and expected functions of health units' personnel on leprosy, clinical examination is the accepted method in this study. As Browne mentioned, ${ }^{9}$ this method is sufficient to diagnose most of the new cases as well as to confirm the type of leprosy of the old registered cases. However, for suspected cases, biopsy and smear examinations were undertaken by specialists.

\section{Results}

The screening was completed within 11 days at Bahçesaray, and within 10 days at Çaldıran. In both study areas, all the villages were reached and 6841 people at Bahçesaray, and 9007 at Çaldıran were examined. When these figures are compared with those of census results undertaken in the region 4 years ago, it will be noted that the numbers cover $68.5 \%$ of population in the first area and $76 \cdot 2 \%$ of population in the second one. It has not been possible to reach higher figures. The team members have tried to find the reasons for this discrepancy and concluded that either the census figures did not reflect the truth, or that perhaps an inland emigration had taken place during the four years, or some people were temporarily away from their villages. But those who were willing to undergo medical examination remained there at the time. With the help of the health personnel who knew the areas sufficiently well, and the cooperation of the respected elderly villagers, house-to-house screening was conducted. The screening was not considered completed until the teams were sure every individual had been examined. It has therefore been concluded that the difference between the number of people examined and the census figures can only be explained by the census figures being incorrect. It is estimated that the proportion of the people who were absent during the screening and of those who did not accept the examination could not exceed $10-15 \%$ of the population registered by the previous census.

It may be concluded that the results of the screening could represent the communities within $95 \%$ confidence interval and 3 per 10,000 reliability limits for those examined in Bahçesaray and 4 per 10,000 reliability limits for those 
examined in Çaldıran. Findings of the screening activities are summarized in Tables 1 and 2. Age and sex distribution of new cases are given in Table 3.

Since the old registered cases had previously only DDS monotherapy all of these cases together with the newly registered ones have been taken under the MDT programme according to the type of their disease. ${ }^{10}$

\section{Time-Effectiveness}

The screening was completed within a period of 21 days. An average of 622 individuals were examined in a day at Bahçesaray where working conditions were extremely unfavourable, whereas in the area of Çaldıran the figure reached was up to 901 because of better working conditions there. The screening teams worked net $7.2 \mathrm{~h}$ per day at Bahçesaray and $6.0 \mathrm{~h}$ at Çaldıran. One team (4 persons) performed a total of 21.5 examinations per hour in the first area and 37.5 examinations per hour in the second area.

Table 1. Findings related to the registered leprosy patients in Bahçesaray and Çaldıran.

\begin{tabular}{|c|c|c|c|c|}
\hline \multirow[b]{3}{*}{ Findings } & \multirow{2}{*}{\multicolumn{2}{|c|}{ Research areas }} & \multicolumn{2}{|l|}{8} \\
\hline & & & \multicolumn{2}{|c|}{ Total } \\
\hline & Bahçesaray & Çaldıran & Number & $\%$ \\
\hline $\begin{array}{l}\text { No. of patients previously } \\
\text { registered }\end{array}$ & 14 & 35 & 49 & $100 \cdot 0$ \\
\hline $\begin{array}{l}\text { No. of previously registered } \\
\text { patients examined }\end{array}$ & 8 & 24 & 32 & $65 \cdot 3$ \\
\hline $\begin{array}{l}\text { Reasons of not being } \\
\text { examined of the remaining } \\
\text { previously registered cases: }\end{array}$ & & & & \\
\hline Died & 4 & 3 & 7 & $14 \cdot 3$ \\
\hline Left area & 1 & 5 & 6 & $12 \cdot 2$ \\
\hline Unknown* & 1 & 3 & 4 & $8 \cdot 2$ \\
\hline $\begin{array}{l}\text { Off registered because of } \\
\text { false diagnosis }\end{array}$ & - & 1 & 1 & $2 \cdot 0$ \\
\hline $\begin{array}{l}\text { No. of previously registered } \\
\text { cases after screening* }\end{array}$ & 9 & 26 & 35 & $71 \cdot 5$ \\
\hline
\end{tabular}

* Unknown cases are not excluded from the lists. 
Table 2. Registered leprosy patients at the end of screening in Bahçesaray and Çaldıran (October 1984).

\begin{tabular}{|c|c|c|c|c|}
\hline \multirow[b]{2}{*}{ Findings } & \multicolumn{2}{|c|}{ Research areas } & \multicolumn{2}{|c|}{ Total } \\
\hline & Bahçesaray & Çaldıran & Number & $\%$ \\
\hline $\begin{array}{l}\text { No. of previously registered } \\
\text { cases after screening }\end{array}$ & 9 & 26 & 35 & $66 \cdot 1$ \\
\hline $\begin{array}{l}\text { No. of new cases found } \\
\text { through screening }\end{array}$ & 7 & 11 & 18 & 33.9 \\
\hline Total cases & 16 & 37 & 53 & $100 \cdot 0$ \\
\hline $\begin{array}{l}\text { History of close contact } \\
\text { among the newly found cases }\end{array}$ & 1 & 5 & 6 & \\
\hline $\begin{array}{l}\text { No. of close contacts } \\
\text { examined* }\end{array}$ & 55 & 89 & 144 & \\
\hline $\begin{array}{c}\text { No. of suspected cases } \\
\text { under surveillance } \dagger\end{array}$ & 23 & 32 & 56 & \\
\hline
\end{tabular}

* These contacts will be periodically examined once a year for five years.

$\dagger$ Cases in this group include those who had uncertain leprosy case(s) among their distant relatives or in their villages, and had rare enlarged solitary peripheral nerves or slightly impaired sensation but did not have skin signs or loss of sensation.

Table 3. Distribution of newly found patients by age and sex.

\begin{tabular}{lrrr}
\hline & \multicolumn{3}{c}{ No. of patients } \\
\cline { 2 - 4 } $\begin{array}{l}\text { Age groups } \\
\text { (in years) }\end{array}$ & Male & Female & Total \\
\hline 9 and less & 2 & 1 & 3 \\
$10-19$ & - & - & - \\
$20-29$ & 6 & 1 & 7 \\
$30-39$ & 3 & 1 & 4 \\
40 and more & 2 & 2 & 4 \\
\hline Total & 13 & 5 & 18 \\
\hline
\end{tabular}


The distribution of these patients according to the clinical forms is as follows:
TT: 1
BT: 4
BB: 1
BL: 4
LL: 3
I: 5

\section{Cost-Eff ectiveness}

The project was financed by the Van and Environs Development Foundation. Transport and local health personnel were provided by the Ministry of Health and Social Assistance. For the purpose of cost estimations, the exact values of new materials to be used in operations have been fully taken into account, but the cost of used materials has been omitted. No extra wages have been paid either to the team members or to the health personnel. They were only provided with food, lodging and transportation, the latter consuming the greater portion of the limited budget (US\$1877). Food expenses amounted to US\$ 612 and the total expenditure reached to US $\$ 2850$ averaging US\$ 137.70 per day and US\$ 0.18 per screened person.

Though a more extensive discussion of our findings in respect of this mass screening project could be expected, the diversified nature of the population examined has at this stage prevented us from making generalizations. It is planned to continue and expand these studies in the future and to report our findings and conclusions in the medical press.

\section{References}

1 WHO. Leprosy, Weekly Epi. Rec. 19 Jan 1979, 54: (3), Geneva.

2 WHO. Leprosy surveillance. Weekly Epi. Rec. 1 June 1984, 590: (22), Geneva.

${ }^{3}$ Dominguez MY. Report for a visit to Turkey. WHO documents, 1967.

${ }^{4}$ SSYB. Health Statistics Yearbook of Turkey 1961-83.

5 TBMM. 224 sayll Yasa. K.T. 5.1.1961.

${ }^{6}$ Taşpınar A. et al. Lepralı olgularin son 4 yılda, yaşgrupları ve cinse göre gösterdiği değiiklikler. Lepra Mecmuasi, 1980, 11: (4), Ankara.

7 Browne SG. Leprosy in Turkey I. National Leprosy Seminar, Istanbul University, Faculty of Medicine. 1980.

8 OMS. Epidémiologie de la Lèpre et lutte antilépreuse, Série de Rapports techniques 716, 1985, Genève.

9 Browne, SG. The Diagnosis and Management of Early Leprosy, The Leprosy Mission, 1984, London.

${ }_{10}$ WHO. Chemotherapy of Leprosy for control programmes, Technical Report Series 675, 1982. Geneva. 